\title{
Integrated bariatric surgery residency
}

This article was published in the following Dove Press journal:

Diabetes, Metabolic Syndrome and Obesity: Targets and Therapy

13 November 2014

Number of times this article has been viewed

\section{Adam EM Eltorai}

Warren Alpert Medical School of Brown University, RI, USA
Correspondence: Adam EM Eltorai Alpert Medical School, Brown University, Box G-9247, Providence, RI 02903, USA Email adam_eltorai@brown.edu
Abstract: Obesity is a major public health concern. Given its lasting efficacy for improving obesity and obesity-related diseases, bariatric surgery is an increasingly common treatment option. As the implementation of the Affordable Care Act progresses, the impending physician shortage will become more severe. Thus there will be an even greater need for doctors specialized in the management and treatment of obese patients. The development of integrated bariatric surgery residency programs could be considered and is discussed herein.

Keywords: obesity, bariatric surgery, integrated residency, surgery education

\section{Background}

Obesity is a major public health concern. ${ }^{1}$ More than one third of adults in the United States are classified as obese. ${ }^{2}$ The prevalence and severity of obesity continues to increase. ${ }^{3}$ Obesity increases the risk for many chronic diseases, including type 2 diabetes mellitus, cardiovascular disease, hypertension, stroke, dyslipidemia, osteoarthritis, some cancers, nonalcoholic fatty liver disease, and decreases overall quality of life. ${ }^{2,4}$ If obesity is not controlled, the current generation may have a shorter life expectancy than the previous generation. ${ }^{2}$

Given its lasting efficacy for improving obesity and obesity-related diseases, ${ }^{5}$ bariatric surgery is an increasingly common treatment option. ${ }^{6}$ As the implementation of the Affordable Care Act progresses, the impending physician shortage will become more severe. ${ }^{7}$ Thus there will be an even greater need for doctors specialized in the management and treatment of obese patients.

The development of integrated bariatric surgery residency programs could be considered. These modified general surgery residencies would place greater focus on treatment of morbidly obese patients. By incorporating the traditional one-year minimally invasive and bariatric surgery fellowship training, the bariatric surgery residents could complete more bariatric-specific training in overall less time.

The number of bariatric surgeons has increased in recent years, ${ }^{8}$ suggesting the field is of increasing interest. It is difficult to predict the exact number of new physicians this residency might interest. However, if the competitiveness ${ }^{9}$ of other integrated (plastic, vascular, and cardiothoracic) surgical residency programs is an indicator, integrated bariatric surgery residency programs may be highly sought after by medical school graduates. 


\section{Conclusion}

The Accreditation Council for Graduate Medical Education (ACGME) could create a Primary Certificate in Bariatric Surgery, eliminating the requirement for certification in general surgery prior to certification in bariatric surgery. Because bariatric surgery includes a substantial component of general surgery, a thoughtful modification of general surgery residency program structure will have to occur to enable the expedited training without loss of core surgical competency. Leaders in bariatric surgery, general surgery, and ACGME can use other integrated programs that similarly combined fellowship training into residency as models for developing strong integrated bariatric surgery programs.

Fundamentally, the goal of such programs would be to treat the growing obesity epidemic by most efficiently producing highly trained bariatric surgeons.

\section{Disclosure}

The author has no conflicts of interest to disclose in this work.

\section{References}

1. National Institutes of Health. Clinical guidelines on the identification, evaluation, and treatment of overweight and obesity in adults: the evidence report. Obes Res. 1986;6(Suppl 2):51S-209S.

2. Catenacci VA, Hill JO, Wyatt HR. The obesity epidemic. Clin Chest Med. 2009;30(3):415-444, vii.

3. Sturm R. Increases in morbid obesity in the USA: 2000-2005. Public Health. 2007;121:492-496.

4. Burton BT, Foster WR, Hirsch J, VanItallie TB. Health implications of obesity: NIH consensus development conference. Int J Obes Relat Metab Disord. 1985;9:155-169.

5. Buchwald H, Avidor Y, Braunwald E, et al. Bariatric surgery: A systematic review and meta-analysis. JAMA. 2004;292(14):1724-1737.

6. Giusti V, Suter M, Heraief E, Gaillard RC, Burckhardt P. Rising role of obesity surgery caused by increase of morbid obesity, failure of conventional treatments and unrealistic expectations: trends from 1997 to 2001. Obes Surg. 2003;13:693-698.

7. Cooper RA, Getzen TE, McKee HJ, Laud P. Economic and demographic trends signal an impending physician shortage. Health Aff (Millwood). 2002;21(1):140-154.

8. Nguyen NT, Masoomi H, Magno CP, Nguyen XM, Laugenour K, Lane J. Trends in use of bariatric surgery, 2003-2008. J Am Coll Surg. 2011;213(2):261-266.

9. Super N, Tieman J, Boucher K, Rockwell WB, Agarwal JP. Recent trends in applicants and the matching process for the integrated plastic surgery match. Ann Plast Surg. 2013;71(4):406-409.

\section{Publish your work in this journal}

Diabetes, Metabolic Syndrome and Obesity: Targets and Therapy is an international, peer-reviewed open-access journal committed to the rapid publication of the latest laboratory and clinical findings in the fields of diabetes, metabolic syndrome and obesity research. Original research, review, case reports, hypothesis formation, expert opinion and commentaries are all considered for publication. The manuscript management system is completely online and includes a very quick and fair peer-review system, which is all easy to use. Visit http://www.dovepress.com/testimonials.php to read real quotes from published authors. 